ks. Wojciech Zyzak

Uniwersytet Papieski Jana Pawła II w Krakowie

\title{
Recenzja książki Wokót „Dziennika” o. Piotra Semenenki CR
}

Oddana do rąk czytelnika książka ${ }^{1}$, której przedmiot refleksji stanowi Dziennik sługi Bożego o. Piotra Semenenki ukazuje się jako VIII tom dobrze znanej i cenionej nie tylko w środowisku teologów duchowości serii Duchowość Klasztorów Polskich: Przekaz i Komunikacja. Publikacja została przygotowana w związku z 200. rocznicą urodzin Piotra Semenenki (1814-1886), współzałożyciela i przełożonego generalnego zmartwychwstańców; wybitnego filozofa, teologa, mentora, kierownik duchowego i spowiednika wielu późniejszych błogosławionych i świętych; założyciela i pierwszego rektora Kolegium Polskiego w Rzymie; współtwórcy i doradcy licznych zgromadzeń zakonnych. Ten wybitny przedstawiciel polskiego duchowieństwa zasługuje na pogłębione badania i popularyzację, czego doskonały przykład dają nam autorzy poszczególnych rozdziałów, w tym również redaktor całej serii.

Właśnie osoba redaktora serii, księdza profesora Wojciecha Misztala, gwarantuje - również w obecnym tomie - wysoki poziom naukowy, połączony z komunikatywnością i przystępnością języka. Integralna i interdyscyplinarna analiza Dziennika zaowocowała interesującymi artykułami z dziedziny filozofii (zwłaszcza antropologii), teologii, w tym duchowości i mistyki, nauk społecznych, a nawet literaturoznawstwa. Tak szerokie spektrum zagadnień świadczy o wyjątkowych intelektualnych i duchowych horyzontach sługi Bożego i jego wielkim znaczeniu dla badań nad historią zmartwychwstańców.

Szczególnie dwa artykuły zamieszczone w książce stanowią doskonałą okazję do zapoznania się z twórczością literacką ojca Semenenki. Najpierw ks. dr hab. Janusz Królikowski, profesor Wydziału Teologicznego w Tarnowie,

\footnotetext{
${ }^{1}$ Red. ks. W. Mleczko CR, seria Duchowość Klasztorów Polskich: Przekaz i Komunikacja, t. VIII, red. serii ks. W. Misztal, Wydawnictwo św. Jana Pawła II, Kraków 2014, stron 168.
} 
ukazał bogactwo i różnorodność literacką pism sługi Bożego. Cenne w tym opracowaniu jest ukazanie tego, co łączy badane pisma, czyli jedności teologicznej idei szeroko pojętej mistyki. Ksiądz Królikowski pokazał również wyraźnie, jak bardzo autentyczna mistyka wpływa na efektywność aktywności ludzkiego życia. Z kolei ks. dr Kazimierz Wójtowicz, znany poeta i pisarz, ukazał Dziennik jako rodzaj relikwii. Jego artykuł stanowi dokładne studium formy, treści, okoliczności powstania, historii publikacji i znaczenia dla zgromadzenia omawianego dziennika.

Pozostałe opracowania pozwalają spojrzeć na badany tekst z punktu widzenia jakiejś konkretnej dziedziny nauki. Ks. dr Kazimierz Mikucki, wykładowca filozofii w wyższym seminarium duchownym we Lwowie, zajął się obecnością filozofii w badanym Dzienniku. Jego artykuł wykazał dobitnie, że ks. Semenenko interesował się żywo i często zajmował filozofią, pragnąc nie tylko zgłębiać zagadnienia teoretyczne, metodologiczne, epistemologiczne czy z zakresu teorii bytu, ale również znaleźć dla nich zastosowanie w teologicznie pogłębionym duszpasterstwie. Pod nieco innym kątem dr Marek Mariusz Tytko, historyk sztuki i nauczyciel akademicki Uniwersytetu Jagiellońskiego, zbadał występowanie i znaczenie w Dzienniku takich kluczowych dla antropologii filozoficznej i pedagogiki zmartwychwstańczej terminów, jak: „człowiek”, „ludzie” i „ludzki”. Wykazał, że sługa Boży, stosując predykaty przymiotnikowo-rzeczownikowe, ujmował antropologiczne określenia w konkretnych zestawach, które rzucają nowe światło na jego, tak istotne dla filozofii i pedagogiki, rozumienie człowieka.

Kolejne rozdziały książki skupiają się wprost na niezwykle interesującej kwestii duchowości Piotra Semenenki. Ks. prof. dr hab. Wojciech Misztal, kierownik Katedry Duchowości Mediów i Relacji Społecznych Wydziału Nauk Społecznych UPJPII, zgłębił temat dotyczący relacji duchownego i duchowości do życia społecznego. Autor ukazał olbrzymi wpływ duchowości i duchownych, w tym również samego Semenenki, na ówczesne życie narodowe. Nie uciekał przy tym od wyciągania konstruktywnych wniosków dotyczących współczesności w takich obszarach, jak: polityka, relacja Kościoła do społeczeństwa, sprawiedliwość społeczna, troska o potrzebujących, wychowanie, szkolnictwo i komunikacja społeczna. Badania nad Dziennikiem pozwalają wysnuć ogólny, ale ważny wniosek, że na życie społeczne należy patrzeć całościowo, uwzględniając również potrzebę duchowości.

Kolejny artykuł zamieszczony w książce dotyczy szczytu życia duchowego. Ks. prof. dr hab. Stanisław Urbański, kierownik Katedry Teologii Życia Duchowego Wydziału Teologicznego UKSW, opracował na podstawie Dziennika dynamizm życia mistycznego. Dogłębna analiza tekstu pozwoliła autorowi zidentyfikować rozwój życia mistycznego sługi Bożego aż do najwyższego zjednoczenia miłości z Bogiem. 
Nie ulega wątpliwości, że wszystkie zamieszczone w książce opracowania stanowią cenny wkład w coraz głębsze rozumienie nie tylko osoby i dzieła Piotra Semenenki, ale także całego dziedzictwa zmartwychwstańców, ich charyzmatu, historii i duchowości. Warto dodać, że artykuły oparte są na tekstach źródłowych, a nawet w dużym stopniu archiwalnych. Dlatego VIII tom serii na temat duchowości klasztorów polskich charakteryzuje się źródłowością, nowatorstwem i profesjonalizmem. Winien zapoznać się z nim każdy, kto interesuje się duchowością chrześcijańską. 
